\title{
Bilim ve Sanat Merkezlerinde Görev Yapan Görsel Sanatlar Öğretmenlerinin Özel Yetenekli Öğrencilerin Sanat Eğitimine İlişkin Görüssleri ${ }^{1}$
}

\author{
DOI: $10.26466 /$ opus.581375
}

*

\author{
Faruk Levent* - Filiz Kansu Çelik** \\ * Doç. Dr, Marmara Üniversitesi, Atatürk Eğitim Fakültesi, İstanbul / Türkiye \\ E-Posta: faruk.levent@marmara.edu.tr \\ ORCID: $\underline{0000-0003-3429-6666}$ \\ ** Doktora Öğrencisi, Gazi Üniversitesi, Eğitim Bilimleri Enstitüsü, Ankara / Türkiye \\ E-Posta: kanfiliz@gmail.com \\ ORCID: $\underline{0000-0002-8999-3947}$
}

\section{Öz}

Bu çalışmada, Bilim ve Sanat Merkezlerinde görev yapan görsel sanatlar öğretmenlerinin özel yetenekli öğrencilere verilen sanat eğitimine ilişkin görüşleri belirlenmeye çalışılmıştır. Araştırma, nitel araştırma yaklaşımlarından durum çalışması deseni ile tasarlanmıştır. Katılımo seçiminde amaçlı örnekleme yöntemlerinden ölçüt örnekleme kullanılmıştır. Bu çalışmanın verileri, yüz yüze görüşme ve yarı yapılandırılmış görüşme formu kullamılarak elde edilmiş̧ir. Araştırma kapsamında altı farklı Bilim ve Sanat Merkezinde çalışan 12 görsel sanatlar öğretmeniyle görüşmeler yapılmıştır. Görüşmeler sonucunda elde edilen veriler, betimsel analizine tabi tutulmuş ve temalar altında toplanarak bu temalara bağlı kodlar oluşturulmuştur. Katılımcı öğretmenlerin görüşleri; BILLSEM'lerin fiziksel olanakları, BILLSEM'lerde görsel sanatlar dersi, BİLSEM'e öğrenci seçim süreci ve öğretmenlerin aldıklarn geri bildirimler olmak üzere dört ana tema altında toplanmıştır. Elde edilen bulgulara göre katılımcı öğretmenler; bilim ve sanat merkezlerindeki sanat eğitimine ilişkin ders içinde kullanılan etkinlik kitabının ihtiyaçlar tam olarak karşılayamamasına, fiziksel şartların, öğrenci seçme sürecinde kullanılan yöntemlerin ve görsel sanatlar eğitimi için ayrulan ders süresinin yetersizliğine dikkat çekmişlerdir.

Anahtar Kelimeler: Bilim ve Sanat Merkezi, görsel sanatlar öğretmeni, özel yetenekli öğrenci, sanat eğitimi

\footnotetext{
${ }^{1}$ Bu çalışmanın ilk hali, 5. Uluslararası Üstün Yetenekliler ve Eğitimi Kongresi'nde (4-6 Mayıs 2018, Gaziantep/Türkiye) sözlü bildiri olarak sunulmuștur
} 


\title{
The Opinions of Visual Arts Teachers' on Art Education of Gifted and Talented Students in Science and Art Centers
}

\begin{abstract}
The purpose of the study was to examine the opinions of visual arts teachers' on art education of gifted and talented students in science and art centers in Turkey. In the study, the case study design was used which is one of the qualitative research approaches. Criterion sampling from the purposeful sampling methods was used in the selection of the participant. The data of this study were obtained by using faceto-face interview and a semi-structured interview form. Within the scope of there search, interviews were held with 12 visual arts teachers working in six different science and art centers. The data obtained from the interviews were subjected to descriptive analysis and main themes and codes related to these themes were created. The opinions of the participating teachers; the physical possibilities of BILSEMs, visual arts course in BILLSEMs, student selection process to BILLSEM and the feedback received by teachers were gathered under four main themes. As a result of the findings, participating teachers pointed out that the activity book used in science and art centers could not meet the needs, the physical conditions, the methods used in the student selection test and the time inadequacy for the course.
\end{abstract}

Keywords: Science and art center, visual arts teacher, gifted and talented student, art education in Turkey 


\section{Giriş}

Milli Eğitim Bakanlığı tarafından üstün yetenekli birey; zekâ, yaratıcılık, sanat, spor, liderlik kapasitesi veya özel akademik alanlarda akranlarına göre yüksek düzeyde performans gösteren birey olarak tanımlanmaktadır (MEB, 2012). Üstün yetenekli öğrenciler, potansiyel açıdan akranlarına göre öğrenme hızı, öğrenme derinliği ve sahip oldukları ilgiler bakımından farklıdır. Bu öğrenciler, normal programlar yolu ile sağlanamayan geniş kapsamlı eğitim olanakları ve hizmetlerine gereksinim duyarlar (Renzulli ve Reis, 1985).

Bilim ve Sanat Merkezleri (BİLSEM) ilk olarak 1995 yılında Millî Eğitim Bakanlığı bünyesinde okul öncesi, ilköğretim ve ortaöğretim kurumlarına devam eden üstün yetenekli öğrencilerin örgün eğitimleri dışındaki zamanlarda ilgi ve yetenekleri doğrultusunda eğitim almalarını sağlamaya yönelik açılmıştır (Levent, 2014). Bu merkezlerde yöntem olarak öğrencilerin kendi seçtikleri projeler etrafında kendilerinin geliştirdikleri çözümü uygulamaları ve bu süreç içerisinde öğrenmeleri temel alınmaktadır (Levent, 2011b).

BİLSEM'e kayıtları yapılan öğrenciler; a) Uyum, b) Destek eğitimi, c) Bireysel yetenekleri fark ettirme, ç) Özel yetenekleri geliştirme, d) Proje üretimi ve yönetimi eğitim programlarına alınırlar. Özel yetenekleri geliştirme programı da müzik ve görsel sanatlar yetenek alanından uyum programını, genel zihinsel yetenek alanından ise bireysel yetenekleri fark ettirme programını tamamlayan öğrencilerin özel yeteneklerini geliştirmek amacıyla yürütülen eğitim programıdır. Öğrencilerin özel yetenek alanı/alanlarına yönelik bilimsel ve sanatsal etkinlik temelli çalışmalara özel yetenekleri geliştirme programı döneminde yoğunluk kazandirilır (MEB, 2015).

BİLSEM'lerin amac1; "özel yetenekli öğrencilerin; bilimsel düşünce ve davranışlarla estetik değerleri birleştiren, üretken, sorun çözen, kendini gerçekleştirmiş bireyler olarak yetişmeleri, yetenekleri ve yaratıcılıklarını erken yaşta fark ederek en üst düzeyde kullanmalar, özel yetenekleri doğrultusunda bilimsel çalışma disiplini kazanmaları, disiplinler arası düşünme, sorunları çözme, belirlenen ihtiyaçları karşılamaya yönelik projeler gerçekleştirmelerini sağlamak" olarak açıklanmaktadır (MEB, 2015, s.2). Ayrıca BİLSEM'lerde sanat eğitimi, üstün yetenekli öğrencilerin kişilik eğitimleri için bir araç olarak 
kullanılmaktadır (Danış, 2017). İlgili literatür incelendiğinde, sanat eğitiminin öğrencilerin kişilik gelişimlerini ve davranışlarını olumlu yönde etkilediğini belirten birçok kaynağa rastlanmaktadır (Yetkin, 1962; Baltacıŏlu, 1971; Hurwitz ve Day, 1995; Aral, 1999; Mercin ve Alakuş, 2007; Yılmaz, 2007; Yolcu, 2009; Buyurgan ve Buyurgan, 2012).

Sanat eğitimi genel eğitim gibi zihinsel gelişimi sağlayan, öğrencilerin yaratıcılıklarını ortaya çıkartan bir eğitim aracı olmasının yanında görsel estetiğe dayalı ihtiyaçları karşılamakta ve öğrencinin psikolojik ihtiyaçlarının da doyurulmasına katkı sağlamaktadır. Bu özelliği ile sanat eğitimi, genel eğitimin vazgeçilmez bir parçasıdır. Başka bir ifadeyle sanat, duygu ve düşünce arasındaki iç içe geçmiş bağlantıyı vurgularken, öğrenme ve gelişim sürecinin de bir yardımcısı olmaktadır (Mercin ve Alakuş, 2007; Yolcu, 2007).

Sanat eğitimi; yaratıcılık eğitiminin ön planda tutularak ıraksak düşünmenin geliştirildiği, her öğrencinin kişisel gelişimi ve eğilimleri doğrultusunda yönlendirilmeye çalışıldığ amaçları çocuğu/genci görmeye, aramaya, sormaya, deneme yapmaya, sonuçlandırmaya yöneltmektir. Sanat eğitiminin bu amaçlarını gerçekleştirebilmesi için eğitimin her kademesinde, kesintiye uğramadan, seviyeye uygun programlarla yerini alması önemlidir. Özellikle teknolojinin hızla ilerlediği, makineleşmenin bazı sorunları da beraberinde getirdiği günümüzde çocuğa/gence kendini farklı sanatsal yollarla ifade edebilme ortamları hazırlamak, mutlu ve üretken bireylerin yetiştirilmesi için de gereklidir (Buyurgan ve Buyurgan, 2012).

Üstün yetenekli öğrencilerin sanat eğitiminde program oluşturulurken; öğrencilerin ilgisini çekecek temalar seçilmeli, bu temalara uygun olan materyaller ve bunların nasıl temin edileceği belirlenmeli, programda üzerinde önemle durulması gereken noktaların neler olduğuna karar verilmeli, eğitime nereden ve nasıl başlanacağı iyi bir şekilde planlanmalıdır. Ayrıca üstün yetenekli öğrenciler için geliştirilen sanat eğitimi programlarında, öğrencilerin üst düzey düşünme becerilerine sahip olduğu göz önünde bulundurulmalı ve program bu doğrultuda planlanmalıdır (Clark ve Zimmerman, 2004; akt. Yücel, 2012).

Üstün yeteneklilerin eğitiminde öğretmenlerin kritik görevleri vardır. Öğretmenlerin, sinıflarında bulunan özel yetenekli öğrencileri fark edebilmesi ve onlara yönelik farklı öğretim stratejileri uygulayabilmesi için 
bu alanla ilgili yeterli bilgi altyapısına sahip olmaları gerekir. Öğretmenlerin bilgi altyapısı zayıfsa bu görevlerini tam olarak yerine getiremezler ve bu öğrenciler toplumda fark edilmeden çoğunluk içinde kaybolabilir (Sak, 2010; Levent, 2011b). Başka bir ifadeyle öğretmenlerin yeterli ve nitelikli eğitim almış olmaları, üstün yetenekli bireylerin potansiyellerini tam anlamıyla kullanmaları açısından büyük önem taşımaktadır (Robinson, Shore ve Enersen, 2007).

Çocuğun/gencin çizgisel gelişimini bilen, onu tanıyan, müze gezme bilinci gelişmiş, müzede öğrenmenin kazanımlarına inanan, öğrencilerine hangi seviyede ne kadar bilgilendirme yapacağını, uygulama boyutunda hangi konuların daha uygun olabileceğini, hangi malzemeleri, yöntem ve teknikleri kullanacağını bilen görsel sanatlar öğretmenleri gelecek nesillerin sanatsal açıdan nitelikli yetişmesinde çok önemli rol oynamaktadır (Buyurgan ve Buyurgan, 2012).

Türkiye Büyük Millet Meclisi (TBMM)'nin “Üstün Yetenekli Çocukların Keşfi, Eğitimleriyle İlgili Sorunların Tespiti ve Ülkemizin Gelişimine Katkı Sağlayacak Etkin İstihdamlarının Sağlanması Amacıyla Kurulan Meclis Araştırması Komisyonu Raporu"nda üstün yetenekli çocukların, üniversiteler tarafından açılacak sertifika programlarını bitiren öğretmenlerce eğitilmeleri gerektiği belirtilmiştir. Bu raporda, bilim ve sanat merkezlerine öğretmen seçiminde fen liseleri ve anadolu liselerinde görev alacak öğretmenlerin seçiminde kullanılan kriterlere benzer kriterler getirilmesi gerektiği belirtilmektedir (TBMM, 2012).

Üstün yetenekli bireylere öğretmenlik yapacak kişilerin kendilerine has, öğrencinin isteklerini ön plana çıkaran programlar geliştirip uygulayan, bireysel farklılıkları göz önünde bulunduran, pozitif davranışları destekleyen, hayal gücüne ve üretkenliğe saygı duyan, konu alanına hakim, bilgi ufkunu genişleten, öğrencilerine inanan, güvenen ve onlara eşit davranan kişiler olmaları gerekir (Altıntaş, 2014). Üstün yetenekli öğrencilere rehberlik edecek öğretmenlerin, bireylerin üstün sanatsal yeteneklerine yetecek kapasiteye sahip olmaları gerekmektedir. Bu bireyleri akranlarından ayıran en önemli özelliklerden biri, üstün sanat yeteneğine sahip olmalarıdır. Büyük sanatçıların çoğu başarılarını; kendilerini bir öğretmenin keşfetmesine ve onu heveslendirerek gerekli eğitime yönlendirmesine borçludur (Cutts ve Moseley, 2004). 
Üstün yetenekli bireylerin sanatsal yetilerini kullanma ve kendilerini gerçekleştirme aşamasında onlara rehberlik edecek öğretmenlerin hayati önemi bulunmaktadır. Bu nedenle öğretmenlerin üstün yetenekli bireyleri aday gösterebilme becerisine sahip olmaları, üstün yetenekli bireylerin özelliklerini bilmeleri gerekmektedir. Ayrıca öğretmenlerin geniş bir yetenek tanımına sahip olmaları gerekmektedir (Karip, 2016). Bu çalışmanın amacı, bilim ve sanat merkezlerinde görev yapan görsel sanatlar öğretmenlerinin özel yetenekli öğrencilerin sanat eğitimine ilişkin görüşlerini incelemektir.

\section{Yöntem}

Çalışmanın bu bölümünde; araştırma deseninden, çalışma grubundan, veri toplama aracindan, verilerin toplanmasından ve verilerin analizden bahsedilmektedir.

\section{Araştırmanın Deseni}

Bu çalışma, nitel araştırma yöntemlerinden durum çalışması ile yürütülmüştür. Durum çalışması nitel araştırmada çok yaygın olarak kullanılan bir yaklaşımdır (Silverman, 2006; Yıldırım ve Şimşek, 2016). Nitel durum çalışmasının en belirgin özelliği bir ya da birkaç durumun derinliğine araştırılmasıdır. 1980'li yıllardan itibaren eğitim araştırmalarında yaygın bir şekilde kullanılmaya başlanmış olan durum çalışmasında, bir duruma ilişkin etkenler bütüncül bir yaklaşımla araştırılır ve ilgili durumu nasıl etkiledikleri ve ilgili durumdan nasıl etkilendikleri üzerine odaklanılır (Cohen, Manion ve Morrison, 2005; Silverman, 2006; Merriam, 2013; Yıldırım ve Şimşek, 2016). Bu araştırmada incelenen durum olarak bilim ve sanat merkezlerinde görev yapan görsel sanatlar öğretmenlerinin özel yetenekli öğrencilerin sanat eğitimine ilişkin görüşleri ele alınmıştır.

\section{Çalışma Grubu}

Araştırmanın çalışma grubu amaçlı örnekleme yöntemlerinden biri olan "maksimum çeşitlilik örnekleme" tekniği kullanılarak belirlenmiştir. Amaçlı örnekleme zengin bilgiye sahip olduğu düşünülen durumların 
derinlemesine çalışılmasına olanak vermektedir (Yıldırım ve Şimşek 2016). Maksimum çeşitliliğin sağlanabilmesi için araştırma kapsamında görüşülecek olan öğretmenlerin belirlenmesi sırasında öğretmenlerin farklı illerdeki BíLSEM'lerde görev yapıyor olmalarına, eğitim durumlarının ve hizmet sürelerinin farklı olmasına dikkat edilmiştir. Bu şekilde 2017-2018 eğitim-öğretim yılında İstanbul, Adapazarı, Malatya, Gaziantep, Şanlıurfa illerindeki BİLSEM'lerde görevli 12 görsel sanatlar öğretmeni çalışmaya dahil edilmiştir. Bu öğretmenlerin, 7'si kadın, 5'i erkektir ve $8^{\prime} \mathrm{i}$ lisans $4^{\prime} \ddot{u}$ lisansüstü eğitim mezunudur. Ayrıca katılımcların en az bir yıldan daha fazla BİLSEM'lerde görev yapıyor olmalarına özellikle dikkat edilmiştir. BİLSEM'lerdeki görsel sanatlar öğretmeni sayısının bir veya iki olması nedeniyle öğretmenlerin kimliklerinin deşifre olmaması adına katılımcıların demografik bilgilerine yer verilmemiştir.

\section{Veri toplama aracı ve verilerin toplanması}

$\mathrm{Bu}$ araştırmada veri toplama aracı olarak görüşme ve yarı yapılandırılmış görüşme formu kullanılmıştır (Coleman, 2012; Christensen, Johnson ve Turner, 2015; Gliner, Morgan ve Leech, 2015; Yıldırım ve Şimşek, 2016). $\mathrm{Bu}$ durum görüşme yönteminin; bireylerin deneyimlerine, tutumlarına, görüşlerine, şikâyetlerine, duygularına ve inançlarına ilişkin bilgi elde etmede başarılı bir yöntem olmasından kaynaklanmaktadır (Yıldırım ve Şimşek, 2016). Görüşme; bireylerin çeşitli konulardaki görüş, tutum, bilgi ve davranışları ile bunların olası nedenleri arasındaki ilişkinin öğrenilmesinde kullanılan en kestirme yoldur. Görüşmede araştırmacı netleşmeyen konularla ilgili anında soru sorma olanağı da bulabilmektedir. Araştırmacı, söylenenlerin yüzeysel anlamının yanı sıra derin anlamlarıyla ilgili de ipuçları yakalayabilir (Karasar, 2015).

Yarı yapılandırılmış görüşme formu yaklaşımı, görüşme sırasında araştırmacıya yöneltilecek sorular veya konular listesini kapsamaktadır (Yıldırım ve Şimşek, 2016). Yarı yapılandırılmış görüşme formu, görüşme süresince farklı sorularla konunun açılmasına, çeşitli boyutların ortaya çıkmasına ve konu hakkında yeni fikirlere ulaşılmasına katkı sağlamaktadır (Merriam, 2013). Yarı yapılandırılmış görüşme formu oluşturulurken öncelikle konu ile ilgili alanyazın incelenmiştir. Alanyazın 
incelenmesinden sonra oluşturulan yarı yapılandırılmış görüşme formu, önce üstün yeteneklilerin eğitimi alanında uzman bir öğretim üyesine daha sonar görsel sanatlar eğitimini alanında bir uzman öğretim üyesine sunulmuştur. Uzman görüşlerinin ardından yarı yapılandırılmış görüşme formunda çeşitli düzenlemeler yapılmıştır. Ardından, yarı yapılandırılmış görüşme formu pilot uygulama olarak iki görsel sanatlar öğretmenine uygulanmıştır. Pilot uygulama sonrasında yarı yapılandırılmış görüşme formuna son şekli verilmiştir.

$\mathrm{Bu}$ araştırmada görüşmelerin organize edilmesi için öncelikle araştırmaya gönüllülük esasına göre katılan görsel sanatlar öğretmenlerinden randevu talep edilmiş, uygun ortam ve zamanda görüşmeler yapılmıştır. Görüşmelere başlamadan önce araştırmanın amacı ve görüşmenin amacı katılımcılara açıç̧a ifade edilmiştir. Ayrıca BİLSEM adı ve şahıs isimlerinin hiçbir şekilde geçmeyeceği ve verilerin bilimsel amaçlar dışında kullanılmayacağı belirtilmiştir. Görüşmeler 30 dakika ile 45 dakika arasında değişen sürelerde gerçekleştirilmiştir.

\section{Verilerin Analizi}

Araştırma verilerinin analizinde betimsel analiz tekniği kullanılmıştır. $\mathrm{Bu}$ analiz türünde elde edilen veriler, araştırma sorularının ortaya koyduğu temalara göre düzenlenebileceği gibi görüşme süreçlerinde kullanılan sorular ya da boyutlar dikkate alınarak da sunulabilir. Bu analizde görüşülen bireylerin görüşlerini çarpıcı bir biçimde yansıtmak için sık sık alıntılara yer verilmektedir. $\mathrm{Bu}$ analizde amaç, elde edilen bulguları düzenlenmiş ve yorumlanmış bir biçimde okuyucuya sunmaktır (Yıldırım ve Şimşek, 2016). Görüşler önce benzer konu başlıkları altında gruplandırılmış, daha sonra görüşler kodlanarak analiz işlemi sonucunda belirli kategoriler altına yerleştirilmiştir. Veriler birbiriyle uyumlu olacak șekilde sınıflandırılarak, alt temalar belirlenmiştir. İlk taslak bittikten sonra analiz tekrar gözden geçirilerek, tekrarlayan veya birbiriyle uyumlu olmayan temalar yeniden sınıflandırılmıştır. Araştırmada kullanılan (./.) işareti görüşme yapılan öğretmen sayısının kaçının aynı görüşte olduğunu göstermek için kullanılmıştır. Ayrıca katılımcı görüşleri verilirken görüşülen görsel sanatlar öğretmen, cinsiyetinin baş harfi ve katılımcı 
numarasından oluşan bir kodla belirtilmiştir. Örneğin K5: 5 numaralı kadın öğretmeni temsil etmektedir.

\section{Bulgular}

Katılımcı görsel sanatlar öğretmenlerinin görüşleri; BİLSEM'lerin fiziksel olanakları, BİLSEM'lerdeki görsel sanatlar dersi, BİLSEM'e öğrenci seçim süreci ve öğretmenlerin aldıkları geri bildirimler olmak üzere dört tema altında toplanmıştır.

\section{BİLSEM'lerin Fiziksel Olanaklan Hakkındaki Görüşler}

Katılımcı öğretmenlerin, BİLSEM'deki fiziksel olanakların sanat eğitimine uygun olup olmadığına ilişkin görüşleri Tablo 1'de verilmiştir.

Tablo 1. BILLSEM'lerin Fiziksel Olanaklarna İlişkin Görüşler

\begin{tabular}{lll}
\hline Tema & Kod & f \\
\hline BíLSEM'lerin fiziksel olanaklar1 & Fiziksel olanaklar yetersiz & 8 \\
\cline { 2 - 3 } & Fiziksel olanaklar yeterli & 4 \\
\hline
\end{tabular}

Tablo 1'de görüldüğü üzere; araştırmaya katılan öğretmenlerden 8'i çalıştıkları merkezin fiziksel olanaklarının sanat eğitimi için yetersiz olduğunu, 4'ü ise fiziksel olanaklarının yeterli olduğunu belirtmiştir.

\section{Fiziksel olanaklarin yetersiz olması}

Bu koda ilişkin katılımcı görüşlerinden bazıları şöyledir:

"Ĕ̆ger atölyelerin türleri ve donanımları arttırılırsa, bilim sanat merkezleri gelecekteki ekolleri oluşturacak öğrencileri yetiştirilebilir. Ancak bunun için merkezlerin fiziksel özelliklerinin yeterli olması gerekiyor. Ama ben bu haliyle yeterli bulmuyorum." (E1)

"Atölyeler sadece geleneksel üretimler yapmaya uygundur. Teknolojik olarak hiçbir ekipman yok. Grafik çizim tableti, 3B Yazıcı, animasyon ve film için ekipman, kamera, fotoğraf makinası gibi ekipmanların olması gerekiyor." (E2)

"Hafta içi öğrencilerin az, hafta sonu daha çok olması atölyenin küçük olmasindan dolayı bazen sorun olabiliyor." (K5) 
"Atölyelerimiz tasarımından itibaren sanata yönelik tasarlanması gerekmektedir bunun yanı sira yeterli donanıma sahip olmamakla beraber merkezlerde bilime daha fazla donanım sağlanmakta olduğundan sanata daha az bütçe ayrilmaktadır." (E5)

"Atölyelerde tüm plastik sanatlar ve geleneksel sanat alanina uygun materyal ve alan olmalıdır." (K1)

"Atölyeler yeterince büyük değil. Eşya, araç, gereç ve malzemelerde yetersiz. Atölye ortamının çok çeşitli sanat alanlarında üretim yapmaya uygun olmasını isterdim." (K6)

\section{Fiziksel olanaklar yeterli}

Bu koda ilişkin katılımcı görüşlerinden bazıları şöyledir:

"Her BILLSEM'in standart bir atölye donanımı yok. Bakanlık bu standardı yakalamak için uğraşıyor. Bizim idaremiz eksiklikleri önemsiyor ve ihtiyaçlarımızı gözetiyor. Okul olarak bizim atölye durumumuz çok yeterli. Ama başka bir ildeki BILLSEM'deki arkadaşlar bizim kadar şansh değiller." (K7)

"Kurumumuz öğrenciler için her türlü imkânı sağlayabilmektedir. Malzeme konusunda sıkıntı yok. Bina içinde depolama, saklama, çalışma alanları için ayrı bölümler olması çok iyi olurdu." (K2)

"Yönetim atölye donanımı ve malzemeler konusunda bize destek oluyor." (K5)

\section{BİLSEM'lerdeki Görsel Sanatlar Dersi Hakkındaki Görüşler}

Katılımcı öğretmenlerin, BİLSEM'lerde görsel sanatlar dersi hakkındaki görüşleri Tablo 2' de verilmiştir.

Tablo 2. BİLSEM'lerdeki Görsel Sanatlar Eğitimine İlişkin Görüşler

\begin{tabular}{lll}
\hline Tema & Kod & f \\
\hline BİLSEM'lerdeki görsel & Ders içinde kullanılan etkinlik kitabı & 12 \\
\cline { 2 - 3 } sanatlar dersi & Dersin niteliği & 10 \\
\cline { 2 - 3 } & Ders için ayrılan süre & 8 \\
\hline
\end{tabular}

Tablo 2'de görüldüğü üzere; araştırmaya katılan öğretmenlerden 10'u BİLSEM'lerdeki görsel sanatlar eğitimi hakkında; 8'i dersin niteliği, 8'i ders için ayrılan süre, $8^{\prime} i$ ise merkezlerde kullanılan etkinlik kitabı 
hakkında görüş bildirmiştir. Bu kategorilere ait görüşlerden bazıları aşağıda sunulmuştur.

\section{Ders içinde kullanılan etkinlik kitabı}

Bu koda ilişkin katılımcı görüşlerinden bazıları şöyledir:

"Etkinlik kitaplarındaki etkinliklerin birçoğunun, özel yetenekli öğrencilere göre hazırlandığını düşünmüyorum. Bu kitaptaki etkinliklerin yerine etkinlikleri birlikte belirlediğimiz için genel olarak sorun yaşamıyoruz." (E1)

"Etkinlik kitabını neredeyse hiç kullanmıyorum." (E2)

"Karateci çocuk filminde 'cilala parlat' bölümü vardı. Ustası gelişmesi için çocuğa basit el hareketleri öğretiyordu, çocuk da sıkılıyordu. Bizdeki öğrenci de kitaptaki etkinlikleri sıkıcı ve gereksiz görüyor. Bunun, onun gelişmesindeki gerekli adımlar olduğunu göremiyor." (K5)

"Özellikle grafik tasarım çalışmaları ilkokul ve ortaokul öğrencilerinin seviyelerine uygun değil. Bazı konularda örneğin Zümrüd-ü Anka Kuşu öğrencilerin çok zorlandıklarl, sinurlandırıcı çalışmalar var. Ek konularla telafi etmeye çalışıyorum. Konular biraz daha öğrencinin yaşantısında olan, çok yönlü düşündürücü, estetik eğitimine katkı sağlayan ve ilgisini çekici olmalıdır" (K6)

"Etkinlik kitabını kullanmıyoruz. Merkezimizde öğretmenlerin hazırlamış olduğu etkinlikleri uygulamaktayız" (E5)

"Bir kılavuz kitabımı mevcut. Buradaki etkinlikleri kullanabiliyoruz kendimiz belirlenen alan kapsamında farklı etkinlikler de yapabiliyoruz. Kılavuza paralel, öğrencilerin yaşlarına göre yaratıcı ve farklı etkinlikleri de sıklıkla hazırlyyorum." (K7)

"Evet, bakanliktan gelen kılavuz kitap öğrencilerin seviyelerine uygun olarak hazırlanmış. Bunun yanında etkinlikte kesin bir şart yok öğrenciyi tanıdıkça ihtiyaçlarına ve eksiklerine göre ben kendim etkinlik hazırlıyorum." (E3)

\section{Dersin niteliği}

Bu koda ilişkin katılımcı görüşlerinden bazıları şöyledir:

"BILLSEM'lerin herkesin çalışamadığ ve gerçekten yetenekli olmayanların eğitim görmediğ $i$, sadece özel bireyleri bünyesinde barmdıran bir kurum olmasin isterdim. Günümüz sanatı, çă̆daş sanatlar bünyesinde tüm tekniklerin harman- 
lanarak kavramsal üretimlerin yapıldı̆̆ı bir alan doğurmuştur. Ayrıca dijital sanatın kendisine oldukça geniş bir alan açtığını görmekteyiz. Video art, performans art gibi alanlarm varlĭg 1 da göz önünde bulundurarak, paralel etkinlikleri öncelemek gerektiğine inanıyorum. Ayrica teori mutlaka olmali; sanat felsefesi, sanat estetiği ve etik mutlak suretle yer bulmalı..." (E2)

"Resim, heykel, baskı resim, seramik gibi. BILSEM'deki öğrenciler bence eğitimlerini akşam almak yerine haftada bir veya yarım günlerini BILLSEM'de eğitim alarak geçirebilirler." (K6)

"BILLSEM'deki sanat eğitimi için. Kısa vadede fazla bir şey yapılmaz, uzun vadeye yayarak yetenekli öğrencilerin kişisel becerilerini göz önüne alınarak çalışmalar yapılabilir." (E3)

"BILLSEM'de öğrencilerin kişisel yetenek ve isteklerine göre her türlü desteğ $i$ alabilmeleri gerek, bu bağlamda ailelerin de eğitime dâhil edilmeleri hem sanatın geleceği hem de toplumdaki sanata karşı olan negatif düşünceyi az da olsa kurabilir ve bunun akabinde geleceğin sanat akımcıların yetiştirmek isterdim." (E4)

"Fiziksel koşulları ile sanata uygun tam donanımlı bir atölye ve öğrencilerin kişisel yetenek ve isteklerine göre her türlü desteği alabilmeleri ve bunun akabinde geleceğin sanatçı, sanata duyarlı ve yaşamla sanatı harmanlaya bilen bireyler yetiştirmek isterdim." (E5)

"Sadece BILLSEM değil bu benim genel bir isteğim keşke resim ve müzik alanında hatta bedensel zekâ olan beden eğitimi ve spor alanında çocuklar okullarda ciddi bir şekilde değerlendirilse ve özel yetenekleri alanında daha yoğun bir program yapılarak eğitim verilse. Yani bu işler BİLSEM sinavlarma kalmasa. Naçizane fikrim tabi. BILLSEM'deki halihazırda eğitim gören tüm öğrenciler için en güzel istek ve değişiklik kendi okullarn ile BİLSEM'lerin birleşerek tek bir okul olarak parçalanmadan eğitim görmelerini istemek sanırım. İki ayr okul saatleri yorucu olabiliyor. Bakanlık BILLSEM'lere son zamanlarda çok önem veriyor. Yapılanlar büyük bir düşüncenin varlığını gösteriyor ama bunca çaba bunca zaman, emek. Gelecekte ne olur bilinmez. Türkiye uzun vadeli plan yapan bir ülke değil, deneme yanılma gidiyor işler. Umarım gelişim ve değişim olumlu olur ve işler bu öğrencilere yurt dışında eğitim imkânı sağlamaya gidecek kadar ilerler, sanat ve sanatçı desteklenir, hak ettikleri şekilde bir BILSEM insanı olurlar." (K7)

"Sanatın önemi ve gerekliliği velilere anlatılmal, BILLSEM'i tamamlayan öğrencilere de üniversite sınavında ilgili alanlara girişte ek puan verilebilir." (K2) 
“Öncelikle sanatın önemi ve gerekliliği velilere anlatılmal. Toplum tarafından kabul görmeyen bir alanda bazen çabalarımız boş kalabiliyor. Hiçbir veli görsel sanatlar alanına gelen öğrencisinin güzel sanatlar alanına ya da bu alanla ilgili bir bölüme devam etmesini istemiyor. Bu alanda öğrencilere ek puan veya teşvik verilebilir". (K1)

\section{Ders için ayrilan süre}

Bu koda ilişkin katılımcı görüşlerinden bazıları şöyledir:

"Gerçek anlamda bir sanat eğitiminden bahsediyorsak eğer, zamanı yeterli bulmuyorum. Ders saati 6 saat olmalı ve haftanın iki gününe bölünmeli. Sanat öğrencilerinin haftada en az iki gün üçer saatlik dersler halinde devam etmesi gerekiyor." (E1)

"Zaman yeterli değil. Üstelik öğrenci sayısı fazla, ders süresi çoğu zaman yeterli olmuyor." (E2)

"Haftada dört saat bence daha uygun. Öğrenciler de süreyi az buluyorlar" (K6)

"Ben bir öğrenci ile haftada 3+3 olmak üzere 6 ders saati çalışıyorum sıkıntı yok yeterli oluyor. İsteğim 4+4 daha uzun süre dağılmadan çalışabilmek. Konsantrasyonu sağladiktan sonra 3 ders de yeterli olabilir ama etkinlikler bazen uzun süreli oluyor. Daha etkili ve kısa sürede bitmesi adına 4 ders saati çok daha verimli olabilirdi. Çocuklarm atölye kavramın kazanmaları için mümkün oldukça ve zaman ayırdıkları müddetçe ders dışı zamanda da gelmelerini tavsiye ve teşvik ediyorum." (K7)

"Bence BILSEM'de görsel sanatlar eğitimine ayrilan süre yeterli." (K3)

"Haftada 4 saat yeterli bir zaman. İstekli ögrenci her zaman buraya gelip çalışabilir." (K1)

"İsteyerek ve farkında olarak gelen öğrenciler için 4 saat yeterli ve verimli geçiyor." (K2)

\section{BÍLSEM'e Öğrenci Seçim Süreci Hakkındaki Görüşler}

Katılımcı öğretmenlerin, BíLSEM'e görsel sanatlar alanında özel yetenekli öğrencilerin seçim süreci hakkındaki görüşleri Tablo 3'te verilmiştir. 
Tablo 3. BİLSEM'e Öğrenci Seçim Süreci Hakkındaki Görüşler

\begin{tabular}{lll}
\hline Tema & Kod & $\mathbf{f}$ \\
\hline BİLSEM'e öğrenci & $\begin{array}{l}\text { BİLSEM'e öğrenci seçmede kullanılan } \\
\text { seçim süreci }\end{array}$ & 7 \\
\cline { 2 - 3 } & $\begin{array}{l}\text { yöntemler işlevsel değil } \\
\text { BİLSEM'e öğrenci seçmede kullanılan } \\
\text { yöntemler işlevsel }\end{array}$ & \\
\hline
\end{tabular}

Tablo 3'te görüldüğü üzere; araştırmaya katılan öğretmenlerden 7'si BİLSEM'e öğrenci seçmede kullanılan yöntemlerin işlevsel olmadığını, 5'i BİLSEM'e öğrenci seçmede kullanılan yöntemlerin işlevsel olduğunu belirtmiştir.

\section{BİLSEM'e öğrenci seçmede kullanılan yöntemler işlevsel değil}

Bu koda ilişkin katılımcı görüşlerinden bazıları şöyledir:

"Sinav formatına ek olarak mülakat sinavinın getirilmesi gerektiğini düşünüyorum. Sanat eğitmeni seçiminde daha dikkatli davranilması ve bu öğretmenlerin seçiminde bir sanatçı akademisyenin bulunması gerek bence. Çünkü tüm bu değişiklikler gerçek anlamda özel yetenekli öğrencilerin seçilmesini ve sonrasındaki alınacak dönütleri direkt olarak etkiliyor." (E1)

"Tek bir sinav uygulaması ile öğrenciyi değerlendirmesinin yeterli olduğunu düşünmüyorum." (K1)

"Ezberlenmiş birkaç figür ile sinavda başarı yakalayıp, ders işleme esnasında bilişsel konularda tıkanıklık yaşıyorlar." (K2)

"Öğrenci belirlenme yöntemleri son derece yanlş̧. Yetenek ve tablet sinavlarına hazırlık kursları olduğu herkesçe bilinmektedir. Öğrenci seçiminin sinavla değil süreçle belirlenmesi gerektiğine inanmaktayım. Hâlihazırdaki sınav bir ön kabul şartı olarak değerlendirilebilir. Ancak kesin kayıtlarının ilk bir yılı sonunda rehber/ders öğretmeninin gözlemleri, istatistikleri, topladığ verileri sonucunda karara bağlanmahıdır. Yaratıcı düşünme ve üretme yetileri gelişmeye açık olmayanlar yılsonunda ayıklanmalıdır. BILSEM'ler verimin en üst düzeyde alındı ̆̆ı kurumlar olmak zorundadır. Herkese değil özel yeteneği olanlara eğitim vermelidir." (E2)

"Bakanlığın bu konuda titiz bir çalışma yürütmesi sonucunda ortaya çıkan bu yöntemler uzman kadrolar tarafindan hazırlanmaktadır. Gözlemlerimiz sonucu doğru yöntemlerdir." (K3) 
"Seçme sinavı çok aşamalı olmalı bence. Adayların desen çalışmasının yanında renkleri de nasıl kullandıklarına bakılmal.."(K5)

“Öğgrenci resimlerini değerlendiren öğretmenlerin alan bilgileri çok iyi değilse, normal gelişim seviyesinde olan öğrenciler üstün yetenekli tanısı alabiliyor. Bu öğrenciler diğer öğrencilerle aralarındaki farkı gördüklerinde sıkıntı yaşıyorlar ve çalışma yapmak istemiyorlar. Bu nedenle değerlendirme sürecinde görev alan öğretmenlerin alanında uzman olması gerekiyor." (K6)

\section{BILLSEM'e öğrenci seçmede kullanılan yöntemler işlevsel}

Bu koda ilişkin katılımcı görüşlerinden bazıları şöyledir:

"Bugüne kadar yapılan yetenek belirleme sinavlarını doğru buluyorum ama bazı eksikleri var. Daha nitelikli öğrencileri belki farkında olmadan sinav seçmeleri esnasında eleyebiliyoruz. Bu yeteneklerin de kaybolmaması için bu çocuklarla bir mülakat da yapılması gerektiğini düşünüyorum. Tüm öğrencilere bunu uygulamak mümkün değilse de en azından ilk 100 kişi ayrıca mülakatlara da alınmalı bence." (E1)

"Bence yapılan bu resim tanılama sinav çok yeterli, bu sinavla yetenekli olan öğrenci zaten ortaya çıkıyor." (K4)

"Öğrenci seçiminde öncelikle bakanlı̆̆ın yapmış olduğu sınavı geçmeleri gerekmektedir. Bu aşamada görsel algısı ve hafizası sinav sonucunu belirlemektedir. $B u$ durum ayn zamanda temeli görseli algılama ve kaydetme, yeri geldiğinde herhangi bir düzleme aktarma bilme becerisini gösterebiliyor ise başarılı olduğu kanaatindeyim." (E4)

"Tanulama sistemi bence başarll ve yeterli imgesel olarak da desen çizimi olarak da kâfi bir tanılama imkânı sağhıyor. Güvenilir de bir ölçme yöntemi uygulanıyor. Sıkıntı belki ilk sınavda resim ve müziköğrencilerine de sayısal bir başarı barajı konmuş olması ama buda BİLSEM adı altında olması gereken bir durum sanırım. Belli bir zekâ ve algılama kapasitesinin olması gerekli." (K7)

\section{Öğretmenlerin Aldıkları Geri Bildirimler Hakkındaki Görüşler}

Katılımcı öğretmenlerin, BİLSEM'lerde görsel sanat eğitimine ilişkin aldıkları geri bildirimler hakkındaki görüşleri Tablo 4 'te verilmiştir. 
Tablo 4. Öğretmenlerin Aldıkları Geri Bildirimler Hakkındaki Görüşler

\begin{tabular}{lll}
\hline Tema & Kod & f \\
\hline Öğretmenlerin & Öğrencilerden aldıkları geri bildirimler & 10 \\
\cline { 2 - 3 } aldıkları geri & Velilerden aldıkları geri bildirimler & 10 \\
\cline { 2 - 3 } bildirimler & Yönetimden aldıkları geri bildirimler & 8 \\
\hline
\end{tabular}

Tablo 4'te görüldüğü üzere; araştırmaya katılan öğretmenlerden $10^{\prime} \mathrm{u}$ öğrencilerden aldıkları geri bildirimler, 10'u velilerden aldıkları geri bildirimler ve 8'i yönetimden aldıkları geri bildirimler hakkında görüş bildirmiştir.

\section{1. Öğrencilerden aldıkları geri bildirimler}

Bu koda ilişkin katılımcı görüşlerinden bazıları şöyledir:

"Her etkinlikten sonra neler öğrendiğimizi tartışıyoruz öğrencilerle, bu esnada aldığım dönütler genel anlamda pozitif oluyor." (E1)

"Ders dışında dahi etkinliklerle ilgili telefonla görüştüğüm fikirlerini dinlediğim rehberlik yaptı̆̆ım öğrencilerim var. Çeşitli yarışmalardan ödül alan öğrencilerim var. Onların motivasyonlarmın giderek yükselmesi oldukça sevindirici. Maalesef ki saylları çok az." (E2)

"Öğrencilerden aldığımız geri dönütler çok güzel, verdiğimizi alan yetenekli öğrencilerle çalışmak çok keyifli." (K4)

"Öğrenciler, çok mutlular ve istekle çalışmalara katılıyorlar." (K6)

“Öğrenciler severek derslere geliyor." (E4)

"Kurumumuzda bulunan öğrencilerimiz katılımları kendi istekleri ve yoğun ilgileri ile gerçekleşmektedir." (E5)

"Öğrenciler etkinlik sonrası başarma hazzını, tam bir ürün oluşturma hazzını yaşıyor." (K7)

\section{Velilerden aldıklarn geri bildirimler}

Bu koda ilişkin katılımcı görüşlerinden bazıları şöyledir:

"Ailelerden aldiğım dönütlerde pozitif ve daha motive edici oluyor." (E1)

"Aileler, öğrencilerinin niçin BİLSEM'de olduğunu tam manasıyla bilmeyen bir kitle. Neredeyse tamamı çocuklarmm sanatla ilgili bir meslek icra etmesine sicak bakmiyor." (E2) 
"Aileler gayet memnun, çünkü çocuklarının ilerlediklerini görüyorlar." (K4)

"Öğrenci de, aile de, yönetim de kaydedilen gelişmeden memnun. Takdir ediliyoruz." (K5)

"Veliler çocukların farklı çalışmalarından, istekli ve mutlu olmalarından dolayı çok memnunlar." (K6)

"Öğrencilerin istekli olması ailelerinde hem eğiticiye hem de resme olan ilgilerinde pozitif etki bırakmaktadır." (E4)

"Çocuklarının istekli olması, ailelerin kurumumuza ve aynı zamanda sanatsal faaliyetlere olan bakış açıların olumlu yönde etkiliyor." (E5)

"Aileler çocuklarında gözlemledikleri özgüvenin gelişmesinden memnun oluyor." (K7)

\section{Yönetimden aldıklarn geri bildirimler}

Bu koda ilişkin katılımcı görüşlerinden bazıları şöyledir:

"Yönetimden aldığım dönütler pozitif ve motive edici." (E1)

"Yönetimler öğrencinin gelişiminden çok; vitrin oluşturma ve üst yönetimlere sunum yapma amacın gütmekte olduğundan içerikten çok görüntüyle ilgilenmektedir." (E2)

"Yönetim her zaman bizleri takdir ediyor." (K4)

"Öğrenci de, aile de, yönetim de kaydedilen gelişmeden memnun. Takdir ediliyoruz." (K5)

"Öğrencinin ve velilerin sanat birimine olan ilgisi, merkez yönetiminin de sanat birimine daha duyarlı olmasımı sağlıyor." (E5)

"Yönetim her daim yanımızda ve destek oluyor; yapılan çalışmaları sergilemekten gurur ve memnuniyet duyuyor." (K7)

\section{Tartışma, Sonuç ve Öneriler}

Toplumların gelişimi, onları oluşturan bireylerin sahip olduğu zekâ, yetenek ve ihtiyaçlarının karşılanmasıyla yakından ilişkilidir. Bireyler iyi eğitilirlerse, içinde yaşadıkları ülke gelişmiş bir teknolojiye, zenginliğe ve dolayısıyla refaha sahip olacaktır. Refah düzeyi yüksek ülkeler bireylere çeşitli ve gerekli imkânları sağlayabilirler. Bireylere gerekli imkânların sağlanması konusunda üstün yetenekli bireylerin ne durumda oldukları çok önemlidir. 
Genel zihinsel yetenekten üstün zekâ tanısı almış öğrencilerin baskın olarak tercih ettikleri öğrenme stilinin görsel ve dokunsal; resim ve müzik alanından üstün yetenek tanısı almış öğrencilerin baskın olarak tercih ettikleri öğrenme stilinin görsel öğrenme stili olduğunu ortaya koymaktadır. Ülkemizdeki BİLSEM'lerdeki öğrenme stillerinin üstün yetenekli bireylerin ihtiyaçlarına göre düzenlenmesi gerektiğinin henüz giderilememiş bir sorun olduğuna şahit olmaktayız (Bildiren, 2013).

Bu araştırmada, BİLSEM'lerde görev yapan görsel sanatlar öğretmenlerinin özel yetenekli öğrencilerin sanat eğitimine ilişkin görüşleri belirlenmeye çalışılmıştır. Yapılan görüşmeler sonucunda elde edilen veriler betimsel analizine tabi tutularak kodlamalar yapılmış ve temalar oluşturulmuştur. Katılımcı öğretmenlerin görüşleri; BİLSEM'lerin fiziksel olanakları, BİLSEM'lerde görsel sanatlar dersi, Bi்LSEM'e öğrenci seçim süreci ve öğretmenlerin aldıkları geri bildirimler olmak üzere dört ana tema altında toplanmıştır.

BILSEM'lerin fiziksel olanakları ile ilgili olarak katılımcıların yarısından fazlası (8/12), BİLSEM'lerde fiziksel şartların yetersizliği yönünde görüş bildirmiştir. Katılımcı öğretmenler özellikle atölyelerin küçük ve yetersiz olduğundan, sanat atölyelerine ayrilan bütçenin yetersizliği, yer sıkıntısı, malzeme eksikliği, öğrencilerin sayısının fazla olması gibi hususları dile getirmişlerdir. Aynı zamanda katılımcılar, görsel sanatlar dersinde kullanılan malzemeleri ve ortaya çıkan ürünleri depolayabilecekleri uygun bir depolama alanına sahip olmadıklarını ifade etmişlerdir. E2 kodlu katılımcının "Atölyeler sadece geleneksel üretimler yapmaya uygundur. Teknolojik olarak hiçbir ekipman yoktur. Grafik çizim tableti, 3B Yazıcl, animasyon ve film için ekipman, kamera, fotoğraf makinası gibi", K6 kodlu katılımcının "Atölyeler yeterince büyük değil. Eşya, araç, gereç ve malzemeler yetersiz" ve E3 kodlu katılımcının "Atölyelerin donanımı ve fiziki şartları sanat eğitimi için yeterli değgil" şeklindeki ifadeleri BíLSEM'lerdeki sanat atölyelerinin ne kadar yetersiz olduğunu göstermektedir. Ayrıca E5 kodlu katılımcının "Atölyelerimiz tasarımından itibaren sanata yönelik tasarlanması gerekmektedir bunun yanı sira donanıml olmamakla beraber merkezlerde bilime daha fazla donanım sağlanmakta olduğundan sanata daha az bütçe ayrılmaktadır." şeklindeki ifadeleri BİLSEM'lerde sanat eğitimine ayrılan bütçe azlığını da göstermektedir. Özkan (2009) tarafından yapılan araştır- 
mada da BİLSEM'lerde yaşanan sorunlardan biri olarak "Bakanlıkça BILLSEM'lere ayrılmış özel bir bütçe olmaması yapılan çalışmaların etkililiğ ini azaltmaktadır." olarak tespit edilmiştir.

BİLSEM'lerdeki fiziksel yetersizlikler; Sezginsoy (2007), Özkan (2009), Yıldız (2010), Şenol (2011) ve Yavuzyılmaz (2012) tarafından yapılan araştırmaların bulgularıyla paralellik göstermektedir. Yavuzyılmaz'ın (2012) çalışmasında atölye gibi ortamların öğrencilerin kullanabileceği kapasitede ve yeterli sayıda olması gerekliliği ortaya çıkmaktadır $(\% 36,36)$. Aynı çalışmada doküman ve kaynakların da arttırılabileceği $(\% 40,91)$ anket sonuçlarında ortaya çıkmıştır. Özkan (2009) tarafından yapılan araştırmada ise BİLSEM'lerde yaşanan sorunlardan birinin "Sosyal etkinliklere götürmek için tahsis edilmiş bir aracının olmaması BİLSEM'lerin örgütsel etkililiğini düşürmektedir" olduğu bulgusuna ulaşılmıştır. Şenol'un (2011) çalışmasında ise BİLSEM öğretmenlerinin, üstün yetenekliler eğitim programlarına yönelik görüşlerini ve karşılaştıkları sorunları araştırmıştır. Araştırma sonucunda, öğretmenlerin çoğunluğunun BİLSEM'lerin fiziki ortam şartları ile ilgili sorunlarla karşılaştıkları tespit edilmiştir.

Sanat eğitimi; sanat tarihi, estetik, eleştiri ve uygulama boyutları ile bir bütündür. Sanat eğitimi sürecinde öğrenciler teorik olarak da doyurulmalı, düşündürülmeli ve konuşturulmalıdır. Uygulama boyutunda ise önce yaptırılacak konu ve teknik ile ilgili görsel materyallerle (yapılabiliyorsa müze ve galeri ziyaretleri ile) teorik bilgilendirmeler yapilmalı, öğrenciler soru ve cevaplarla çalışma öncesi beyin fırtınası yolu ile düşündürülmeli ve uygulamaya sonra geçilmelidir (Buyurgan ve Buyurgan, 2012). Bu araştırmada BİLSEM'lerde görsel sanatlar dersi temasında katılımcıların görüşleri; ders içinde kullanılan etkinlik kitabı, sanat eğitiminin niteliği ve ders için ayrılan süre altında toplanmıştır. Katılımcı öğretmenlerin dördü, BİLSEM'lerde görsel sanatlar eğitimi için ayrılan süre ders saati süresinin yeterli olmadığını ve arttırılması gerektiğini belirtirken, katılımcıların dördü bu sürenin yeterli olduğunu ifade etmiştir. Katılımcıların yarısından fazlası (11/12), etkinlik kitabının yetersiz olduğunu belirtmişlerdir. K6 kodlu katılımcının "Özellikle grafik tasarım çalışmaları ilkokul ve ortaokul öğrencilerinin seviyelerine uygun değil. Bazı konularda örneğin Zümrüd-ü Anka Kuşu öğrencilerin çok zorlandıkları, sınırlandırıcı çalışmalar. Ek konularla telafi etmeye çalışıyorum. Konular biraz daha öğrencinin yaşantısında olan, çok yönlü düşündürücü, estetik eğitimine katkı 
sağlayan ve öğrencinin ilgisini çekici olmalıdır" ifadesi BİLSEM'lerde kullanılan etkinlik kitabının ihtiyacı karşılayamadığını ortaya koymaktadır. E1 kodlu katılımonın "Etkinlik kitaplarındaki etkinliklerin birçoğunun, özel yetenekli öğrencilere göre hazırlandığıı düşünmüyorum." ifadesi de yine diğer katılımcının beyanını destekler niteliktedir.

Üstün yeteneklilerin eğitimini destekleyecek materyallerin seçiminde; öğrencileri kritik düşünmeye sevk etmesi, farklı düşüncelerin üretimini, mantıksal düşünceyi, problem çözmeyi ve iletişim becerilerinin gelişimine teşvik etmesi, araştırmaya olanak vermesi, kişisel yaşantılarla ilgisi olması, alternatif bir öğrenme tarzı sunması ve yeteneklerin gelişimini desteklemesi gibi özelliklere dikkat edilmelidir (Bildiren, 2011). E2 kodlu katılımcının "Günümüz sanatı, çă̆daş sanatlar (contemporary art) bünyesinde tüm tekniklerin harmanlanarak kavramsal üretimlerin yapıldığı bir alan doğurmuştur. Ayrıca dijital art'ın kendisine oldukça geniş bir alan açtı̆̆ın görmekteyiz. Video art, performans art gibi alanlarm varlı̆̆ da göz önünde bulundurarak, paralel etkinlikleri öncelemek gerektiğine inanıyorum." şeklindeki ifadesinden de anlaşılacağı gibi öğretmenler, sanat eğitiminin içeriğinin günümüz ihtiyaçlarına uyarlanmasını, eğitimin niteliğinin arttırılmasını istemekle beraber, üstün yeteneklilik kavramına uygun, günümüz teknolojilerini kapsayan ve bireyin yaratıcllk gelişimini destekleyen bir sanat eğitiminin yoksunluğuna dikkat çekmişlerdir. Bu bulgu, Özkan (2009) tarafından yapılan araştırmanın bulgularıyla paralellik göstermektedir. BİLSEM'de görev alan 91 yöneticinin tümüne, 467 öğretmenden 271'ine, 5056 öğrenciden 479'una, 5056 veliden de 329'una olmak üzere toplam 1170 kişiye ulaşılarak gerçekleştirilen araştırmada BİLSEM'lerde yaşanan sorunlardan ikisinin “Öğrencilerin BİLSEM'de aldıkları eğitim programları, kendi okullarındaki programla bütünlük taşımamaktadır." ve "BILSEM'de program geliştirme dalında uzmanlara ihtiyaç vardır." olarak tespit edilmiştir (Özkan, 2009).

Devletin sanat eğitimi politikalarının, genel eğitim politikalarına bağlı olarak sürekli değişmesinden şikâyetçi olan E3 kodlu katılımcının "BİLSEM'deki sanat eğitimi için kısa vadede fazla bir şey yapılmaz uzun vadeye yayarak yetenekli öğrencilerin kişisel becerilerini göz önüne alınarak çalışmalar yapılabilir." ifadesi dikkat çekicidir. E4 kodlu katılımonın "Ailelerin de sanat eğitimine dâhil edilmeleri hem sanatın geleceği hem de toplumdaki sanata karşı olan negatif düşünceyi az da olsa kırabilir." şeklindeki ifadesi, sanat 
eğitimine ilişkin toplumun bakış açısını olumlu yönde değiştirmek adına önemli bir görüş ortaya koymaktadır. Katılımcı öğretmenler; toplumun ve ailelerin, sanatın gerekliliği ve sanat eğitiminin üstün yetenekliler açısından önemini bilmediklerinden ve hatta kültürden kaynaklanan olumsuz bir bakış açısına bağlı olduğunu ifade etmektedirler. K2 kodlu katılımcının "Sanatın önemi ve gerekliliği velilere anlatılmalı, BILSEM'i tamamlayan öğrencilere de üniversite sinavında ilgili alanlara girişte ek puan verilebilir" şeklindeki ifadesi de kayda değer bir öneridir.

Öğretmenlerin BİLSEM'lere görsel sanatlar alanında özel yetenekli öğrenci seçimi ile ilgili görüşleri yöntemlerin işlevsel olup olmaması olarak iki kod altında toplanmıştır. Katılımcı öğretmenlerin yarısından fazlası (7/12) öğrenci seçim sürecinin işlevsel olmadığı görüşündedir. Özellikle E2 kodlu katılımcının “Öğrenci belirlenme yöntemleri son derece yanlış. Yetenek ve tablet sinavlarına hazırlik kursları olduğu herkesçe bilinmektedir. Öğrenci seçiminin sinavla değil süreçle belirlenmesi gerektiğine inanmaktayım. Hâlihazırdaki sınav bir ön kabul şartı olarak değerlendirilebilir. Ancak kesin kayıtlarının ilk bir yılı sonunda rehber/ders öğretmeninin gözlemleri, istatistikleri, topladığı verileri sonucunda karara bağlanmalıdır. Yaratıcı düşünme ve üretme yetileri gelişmeye açık olmayanlar yılsonunda ayıklanmalıdır. BILLSEM'ler verimin en üst düzeyde alındığı kurumlar olmak zorundadır. Herkese değil özel yeteneği olanlara eğitim vermelidir." şeklindeki ifadeleri, BİLSEM sınavlarına hazırlık kursları ile sınava hazırlanıldığı ve BİLSEM'lere seçim sınavının üstün yetenekli olan öğrenciyi ayırt edebilirliği ile ilgili sıkıntıların olduğunu göstermektedir. E1 kodlu katılımcının "Sinav formatına ek olarak mülakat sinavının getirilmesi gerektiğini düşünüyorum. Sanat eğitmeni seçiminde daha dikkatli davranılması ve bu öğretmenlerin seçiminde bir sanatçı akademisyenin bulunması gerek bence. Çünkü tüm bu değişiklikler gerçek anlamda özel yetenekli öğrencilerin seçilmesini ve sonrasındaki alınacak dönütleri direkt olarak etkiliyor" şeklindeki görüşü de hem sınavın güvenilirliğini ve geçerliliğini hem de seçim sürecinde görevli öğretmen yeterliliğini sorgular niteliktedir. Levent (2011a) tarafından yapılan araştırmada da katılımcı öğretmenlerin tamamına yakını (19/20), "BILLSEM'e öğrenci seçiminde kullanılan işlemlerin sağlıklı işlediğini düşünmüyorum" şeklinde görüş bildirmiştir.

Katılımcı öğretmenlerin verdikleri görsel sanatlar eğitimlerinin sonucunda; öğrenciden, veliden ve yönetimden aldıkları geri bildirimler olmak 
üzere üç kod altında toplanmıştır. E2 kodlu katılımonın "Ders dışında dahi etkinliklerle ilgili telefonla görüştü̈̆̈̈̈m fikirlerini dinlediğim rehberlik yaptı̆̆ım öğrencilerim var. Çeşitli yarışmalardan ödül alan öğrencilerim var. Onlarm motivasyonlarının giderek yükselmesi oldukça sevindirici. Maalesef ki sayıları çok az. Aileler öğrencilerinin niçin BILLSEM'de olduğunu tam manasıyla bilmeyen bir kitle. Neredeyse tamamı çocuklarmın sanatla ilgili bir meslek icra etmesine sıcak bakmıyor. Yönetimler öğrencinin gelişiminden çok; vitrin oluşturma ve üst yönetimlere sunum yapma amacın gütmekte olduğundan içerikten çok görüntüyle ilgilenmektedir" şeklindeki ifadesi oldukça dikkat çekicidir. BİLSEM'lerdeki üstün yetenekli öğrencilerin sanat eğitiminin öneminin ve gerekliliğinin aileleri tarafından anlaşılamamış olması, dahası bu yetilerinin aileler tarafından yetkililere bir gösteriş amacı güdülerek kullanmaları oldukça düşündürücüdür. Ayrıca K2 kodlu katılımcının "Bir sınav ile seçilip buraya gelmek öğrenci ve velilerde gurur uyandırıyor." şeklindeki ifadesi, ailelerin BİLSEM'lerin işlevleri hakkında yeterince derinlemesine bilgi sahibi olmadıklarını, BİLSEM'leri, kendilerinin ve çocuklarının sosyal çevrelerinde bir nevi statü sahibi olmalarını sağlayacak bir araç olarak gördüklerini ortaya koymaktadır. Oysa sanat eğitimi salt bir haz alma durumundan ibaret değildir. Gerçekçi bir eğitim, bilim ve sanatın ayrılmaz işbirliğine dayanmalıdır İnsanda köklü bir gereksinimi karşılayan sanatın, kişiliği eğiten en önemli etmenlerden biri olduğu unutulmamalıdır (San, 1979). Kansu Çelik (2015) tarafından yapılan bir araştırmada bu bulguya paralel olarak bütün yaş grubundaki öğrencilerin görsel sanatlar dersine olan tutumlarının ortalaması oldukça yüksek bulunmuştur (s.84). Bu bulgu, öğretmenlerle beraber öğrencilerin de görsel sanatlar dersine karşı olumlu tutumları olduğunu, görsel sanatlar dersinden zevk aldıklarını ve ortaya çıkan ürünler bağlamında verimli olduklarını göstermektedir. Öğretmenlerin ve öğrencilerin derse olan olumlu tutumları birbirini etkilemektedir ve bu olumlu etkileşimin devam etmesi ve daha da artması için merkez yönetimlerinin dersin işlenişine ilişkin maddi ve manevi anlamda daha fazla katkı sağlamaları önemli görülmektedir.

Toplumun en değerli kaynaklarından biri sayılan ve sayıları sınırlı olan, üstün yetenekli bireylerin kaybedilmemesi, sağlıklı biçimde yetiştirilmesi için ihtiyaç duyulan ortam ve olanakların sağlanması gerekmektedir. Bu bireylere uygun programlarla ve özel yetişmiş eğitimciler 
tarafından eğitim verilmelidir (Levent ve Kansu Çelik, 2017). Özel yetenekli bireylerin eğitiminde, donanımlı ve bilinçli öğretmenlerin yetiştirilmesinin gerekliliği açıktır. Bu açıdan değerlendirildiğinde 1-2 haftalık eğitimlerin öğretmenlerin profesyonel ve mesleki gelişimi için yeterli olmayacağı düşünülmektedir. MEB tarafından düzenlenen hizmet içi eğitim faaliyet programları incelendiğinde, üstün yeteneklilerin eğitimine yönelik faaliyetlerin düzenli aralıklarla yapılmadığ 1 görülmektedir (Özer Keskin, Keskin Samancı ve Aydın, 2013). Özkan (2009) tarafından yapılan araştırmada BİLSEM'lerde yaşanan sorunlardan biri “Öğretmen ve yöneticilerin gelişimine katkı sağlayacak; üstün yeteneklilerin eğitimi ile ilgili hizmet içi eğitim seminerleri yeterli değildir." olarak tespit edilmiştir.

$\mathrm{Bu}$ araştırmada elde edilen bulgular doğrultusunda şu öneriler geliştirilebilir:

- BíLSEM'lere öğrenci seçme sinavlarında kullanılan tanılama aracının (görsel sanatlar alanında özel yeteneği olan öğrencileri ortaya çıaracak şekilde) yeniden gözden geçirilebilir. Bununla birlikte BİLSEM'lere öğrenci seçme sinavinda görev alan öğretmenlerin belirlenmesinde daha hassas ve özenli davranılabilir. Ayrıca öğretmen seçiminde daha bilinçli davranılması için sınav komisyonuna ek olarak alan uzmanı olarak akademisyenlerden de yardım alınabilir.

- Görsel sanatlar için hazırlanan etkinlik kitabında yer alan etkinliklerin üstün yetenekli öğrencilerin sanatsal gelişimine yeterli ve gerekli katkıyı sağlayacak düzeye getirmesine dönük olarak güncellenmesi ve günümüz şartlarına uyarlanması önerilebilir.

- Görsel sanatların öğretimine ilişkin öğrenme ortamı, okul binası ve sınıfla sınırlı olmamalı, çeşitli geziler, sergi ve atölye ziyaretleri ile öğrencilerin öğrenmesi desteklenebilir.

- BíLSEM'lerin, Bilim merkezi ve Sanat merkezi olarak iki ayrı merkez olarak ayrılması önerilmektedir. Böylelikle BİLSEM'lerdeki sanat departmanlarının; bilim departmanlarının gölgesinde kalmayacağı, sanat alanında olağanüstü yetenekli öğrencilerin daha eşitlikçi bir ortamda eğitim almasının mümkün olacağ düşünülmektedir. 
EXTENDED ABSTRACT

\title{
The Opinions of Visual Arts Teachers' on Art Education of Gifted and Talented Students in Science and Art Centers
}

\author{
* \\ Faruk Levent - Filiz Kansu Çelik \\ Marmara University, Gazi University
}

The basics of the visual arts education include a variety of goals, including discovering of one's his skills and abilities, identifying one's position in social domains, recognising one's personality and the socio-cultural values of the society, and being aware of different cultures and respecting these cultures. Therefore, the arts education is required not only for gifted student but also for all students. In Turkey the science and arts centers offer education to gifted students in the field of arts. Beginning from the mid 1990s these centers began to assist the gifted students in their attempts to realize their full potentials in arts.

The aim of the science and arts centers is to assist the raising of gifted students as self-realized individuals who can combine aesthetical values with scientific thinking and acts as well as who are productive and problem-solvers, to help them in using their creativity at the highest level and in developing scientific study habits and to provide them with an opportunity to develop projects concerning multidisciplinary thinking, problem-solving and meeting the needs (MEB, 2015). Gifted students may be defined as those who have higher capacity and rate in creative thinking, can offer fast solutions to problems, have much more developed social skills and can learn much faster. Therefore, such students needs a different educational program due to their disticnt ability and skills. In addition, the education at the science and arts centers offered to gifted students should be shaped in accordance with their educational needs.

Individuals educated at the science and arts centers are given education in relation to adaptation, support, recognition of individual abilities 
and project development and management. Those students who have distinguishing artistic skills are first educated in adaptatiom programs and then they join the programs designed to improve their skills. In the latter program there is a teaching plan in which there is a rich varity of scientific and artistic activities. Such educational programs at the science and arts centers are implemented by teachers.

Arts teachers working at the science and arts centers have very significant effects on the development of the gifted students. However, they have also some critical responsibilites. It is expected that these teachers should recognize the skills of the gifted students and provide necessary education and activities to them to make it possible for them to improve their skills. In order to achieve these goals these teachers should have necessary background in the related fields. Otherwise gifted students cannot achieve their potentials and possible become ordinary individuals over time. Therefore, the teachers working at the science and arts centers should a quality education to meet the educational needs of the gifted students. It means that teachers who guide the gifted students in their attempts to use artistic skills and to realize their potential are crucially important.

Traditional educational approachers assume that students have medium levels of intelligence. It does not specifically consider the educational needs of the students who learn fast or who already have the gains that are planned to teach. Teachers should have the necessary skills to recognize the gifted students and be familiar with the basic characteristics of them. The definition of ability adopted the teachers should be comprehensive. If teachers have a narrow definition the skills of the students cannot be completely evaluated which may result in the unrecognition of gifted students. Another consequence of having a narrow definition of gifted students may be that such student may loose their interest in having an education which is proper for their conditions and that the concept of artistic ability may be isolated from other types of abilities and skills (Karip, 2016). As stated earlier the arts teachers working at the science and arts centers have very significant effects on the development of the artistic abilities of the gifted students. The purpose of the study was to examine the opinions of visual arts teachers' on art education of gifted and talented students in science and art centers. 
This study was conducted with case study of qualitative research methods. The case study is a widely used approach in qualitative research (Silverman, 2006; Yıldırım and Şimşek, 2016). In this research, visual arts teachers working in science and art centers were discussed about the art education of gifted and talented students.

The participants were the visual arts teachers working at six different science and arts centers. More specifically, a total of 12 visual arts teachers interviewed. Of them seven were female and five were male. The data of the study were collected through semi-structured interview forms. The form was developed by the authors based on the review of the related studies. The items developed were reviewed by two field specialists.

The data gathered from the interviews were transcribed and then the data were grouped under the topics. More specifically the opinions of the participants were coded and grouped under the categories. The opinions of the participants are given in relation to the total number. These opinions are given together with the codes indicating the gender and the specific number of the participants. For instance a code like K5: refers to the 5th participant.

As a result of the content analyses the themes were identified. There are four themes and these are categorized as follows: physical opportunities offered by the science and arts centers, arts education given at the science and arts centers, student selection process to the science and arts centers, the feedback given to the teachers about their work with the students and the policies on arts education.

Under the theme of the physical opportunities offered by the science and arts centers a total of 12 teachers offered opinions. There are two major categories under this theme: sufficient physical opportunites and insufficient physical opportunities. Of them the former was supported by eight participants and the latter by four teachers.

Under the theme of the arts education given at the science and arts centers there are three categories as follows: 'the quality of the arts education given at the science and arts centers' 'class hours for the arts education' and 'activity book'. The number of the participants who expressed the views for these categories are 10,8 and 8 , respectively.

Under the theme of the student selection process to the science and arts centers there appear to be two categories: 'nonfunctional methods used in 
the student selection process to the science and arts centers' about which seven participants offered views and 'functional methods used in the student selection process to the science and arts centers' about which five participants offered opinions.

Under the theme of the feedback given to the teachers about their work with the students there are three categories as follows: 'feedback from the students', 'feedback from the parents' and 'feedback from the school administration'. The number of the participants who expressed the opinions for these categories are 10, 10 and 8, respectively.

Under the theme of the teachers' satisfaction from working at the science and arts centers there are two views: those who are satisfied from working there and those who are not. More specifically, eleven teachers are satisfied from working there and only one teacher is not satisfied from working there.

Development of the societies are closely related to meet the needs of individuals in terms of their intelligence and ability. If individuals are educated well they will be instrumental in making the countries technologically developed and rich which make the countries wealthy. On the other hand, those countries of which wealth is high may provide the individuals with opportunities to have necessary development. Meeting the needs of the gifted individuals is one of the significant topics.

Those students who are gifted in terms of general mental abilities usually prefer the learning preference of visual and tactile. However, those are gifted in the fields of arts and music generally prefer the visual learning. One of the problems in regard to the science and arts centers is that the learning preference of the gifted students is not completely taken into consideration (Bildiren, 2013).

In the study the opinions of the visual arts teachers working at the science and arts centers were analysed concerning the arts education offered to the gifted students. The data taken from the interviews were examined through the content analysis and coded. Which produced themes. There are four themes and these are categorized as follows: (1) Physical opportunities offered by the science and arts centers, (2) Arts education given at the science and arts centers, (3) Student selection process to the science and arts centers, (4) The feedback given to the teachers about their work with the students. 
Concerning the physical facilities of the science and arts centers more than half of the participants (8 out of 12) thought that these facilities are not sufficient. More specifically, they stated that workshops are small and insufficient and budget allocated is not enough. They also pointed out that the equipment is not sufficient, but the number of students is very high. In addition, they argued that there is no enough storage for the equipment used in the visual arts classes. The examples for such views are given as follows: "The current workshops are proper for only traditional production. There is no technological devices such as graphic drawing tablets, $3 B$ printers, animation and film equipment, camera, etc." (E2); "Workshops are not big enough and equipment and materials are not sufficient." (K6) and "Physical conditions of the workshops are not appropriate for arts education." (E3). The participant E5 stated that the budget allocated to arts education given at the science and arts centers is very low: "design of the workshops should be eligible for arts education. In addition, they should be properly equipped for it. However, the workshops are much more properly equipped for science education. In other words, the budget for arts education is less." These findings clearly suggest that the center management does not put emphasis on the needs of the arts education. Özkan (2009) also found that one of the problems of the science and arts center is "the lack of a specific budget allocated by the Ministry of National Education for the science and arts centers which result in less efficiency of the centers."

The physical insufficiency of the science and arts centers are also mentioned by the following studies: Sezginsoy (2007), Özkan (2009), Yildız (2010), Şenol (2011) and Yavuzyılmaz (2012). For instance, Yavuzyılmaz (2012) concluded that the workshops should have enough capacity for student work and the number of the workshops should be higher $(36,36 \%)$. In the same study it is found that the documents and resources should be expanded (40,91\%). Özkan (2009) concluded that one of the major problems of the science and arts centers is "The lack of vehicles that may bring students to social activities which reduce the organizational efficiency of the science and arts centers." Şenol (2011) analysed the views of the teachers working at the science and arts centers concerning the educational programs for the gifted students and the potential problems. It is found that the majority of the teachers had problems regarding the physical conditions of the science and arts centers. 
Concerning the category of the arts education given at the science and arts centers there are three categories as follows: 'the quality of the arts education given at the science and arts centers', 'class hours for the arts education' and 'activity book'. Four participants reported that the class hour for visual arts education is not enough and therefore, should be expanded. Another four participants stated that it is proper. More than the half of the participants stated that activity books are not sufficient (8 out of 12). For instance, the participant K6 stated "Especially graphic design studies are not suitable for the level of elementary and middle school students. Some issues such as Zümrüd-ü Anka are very difficult for students, limiting their studies. I'm trying to make up for additional issues. The topics should be more versatile in the life of the student, contributing to the thought-provoking, aesthetic education and attracting the attention of the student." Such a view suggests that the function of the activity books used at the science and arts centers should be questioned.

Teachers mostly support the idea that the content of the visual arts education should be updated in accordance with the current needs, but they also point out that there should be an art education that adapts to today's technologies and supports the development of creativity. This can be seen in the statement by the participant E2 stated 'Modern art and contemporary art have blended all techniques and created an area in which conceptual productions were made. In addition, we have seen a very large area of the digital digital itself. I believe that we must prioritize parallel activities, taking into account the presence of areas such as video art, performance art, etc. Also the Theory must exist; art philosophy, art aesthetics and ethics must also exist in absolute terms." This finding is consistent with the findings by the study carried out by Özkan (2009). In December 2007 this study was implemented on a sample of 1170 people. More specifically 91 center administrators, 271 teachers working at the science and arts centers, 479 students and 329 parents. In the study the major two problems at the centers were found as follows: "The education programs of the science and arts centers should complement those at their schools." and "There is a need for experts in program development at the science and arts centers." (Özkan, 2009).

The participant E3 reported "For arts education in BILSEM, nothing can be done in the short term. Studies can be done considering the personal skills of the talented students by spreading over long term." The participant ME4 stated 
"... The inclusion of families in art education can both improve the future of art and reduce the negative opinions against the art in society." Such views show how society looks at arts education and arts in general. The participants reported that the society and the parents are not aware of the necessity of art and the importance of art education for the gifted people, and even a negative perspective exists in the culture. For instance, the participant K2 stated "The importance and necessity of art should be explained to the parents. The students who complete their education at the science and arts centers can also be given additional points in the university entrance exam."

The opinions of teachers about the selection of gifted and talented students in the field of visual arts to the science and arts centers are grouped under two codes as to whether the selection methods are functional or not. More than the half of the participants (7 out of 12) argued that selection methods are functional. The participant E2 reported "The methods of student selection are extremely wrong. It is well known that there are skills and preparation tests for tablet exams. I believe that student choice should be determined not by exam but by process. The current exam can be considered as a pre-admission requirement. However, at the end of the first year of the final registration, the observations / statistics of the guide / course teacher should be decided upon as a result of the data. Those who lack of creative thinking and production capabilities should be dropped at the end of the year. The science and arts centers must be the institutions with the highest efficiency. Not everyone should be trained like those with special skills." It shows that the students prepare for the examinations through private courses and the selection procedures fail to identify the gifted students. The participant E1 reported "In addition to the exam format, I think the interview exam should be introduced. I think it is necessary to be more careful in choosing an art instructor and to have an artist academician in the selection of these teachers. Because all these changes directly affect the selection of truly gifted students and the subsequent feedback." This opinion questions both the reliability and validity of the examination and the competence of teachers in the selection process. In the study by Levent (2011a) nearly all of the participants (19 out of 20) reported "I do not think that the procedures used in the selection of student to the science and arts centers work well."

One of the most valuable resources of the society are the gifted individuals who are limited in number. They should not be lost. Therefore, the 
environment and opportunities needed to grow in a healthy way should be provided to them. These individuals should be trained by appropriate programs and specially trained trainers (Levent and Kansu Çelik, 2017). When it comes to education of the gifted individuals, it is clear that well trained and conscious teachers should be trained. In this respect, it is thought that 1-2 weeks of education will not be sufficient for the professional development of teachers. When the in-service training activities programs organized by the Ministry of National Education are examined, it is seen that such activities regarding the education of the gifted students are not conducted at regular intervals. (Özer Keskin, Keskin Samancı and Aydın, 2013). As Özkan (2009) stated one of the problems for the science and arts centers is as follows: "In-service training activities about the education of the gifted students which may contribute to the development of teachers and school administrators are not sufficient."

Under the theme of the feedback given to the teachers about their work with the students there are three categories as follows: 'feedback from the students', 'feedback from the parents' and 'feedback from the school administration'. The participant E2 stated "I have students who are guided by me and I talked to on the phone about the events even outside the course. I have students who have won awards from various competitions. It is very pleasing that their motivation is increasing. However, the number of such students is less. Parents are a group who does not know exactly why their students are at the science and arts centers. Almost all of them do not care that their children perform a profession related to art. The center administration aims to create a window and make presentations to senior management, it deals with the image rather than content and rather than students' development." It is quite thought-provoking that the importance and necessity of art education of gifted students at the science and arts centers are not understood by their families, and that these abilities are used by parents with the aim of showing them to the authorities. The participant K2 reported "Picking up with a single examination raises pride in students and parents." These views suggest that parents do not have enough in-depth knowledge of the functions of the science and arts centers and that they see these centers as a means to enable them and their children to have some status in their social environment. However, art education is not a mere pleasure. A realistic education should be based on the inseparable cooperation of science and art. It must be remembered that 
art which meets the fundamental needs of individuals is one of the most important factors that educate their personality (San, 1979).

In our country to be successful in the fields of science and mathematics is the most important condition in order to have a profession having material and spiritual satisfaction. This situation starts to reveal a negative attitude towards the Visual Arts course, and over time this attitude is settled in the society. The current education system in our country has a design which is based on being successful in memorizing exams. Therefore, a situation arises which requires the gifted students to deal with the theoretical courses.

Based on the findings of the study the following suggestions are developed:

- It is thought that the validity and reliability of student selection exams for the science and arts centers should be improved. If necessary, the duration of the exam will be extended and students can be tested again at the end of the first year of their choice and if they can continue their education at the center as a result of the average of the first and second exam results. The selection of the teachers assigned to the exam commissions can be improved. In addition, in such commisions academics may also be assigned as field experts.

- It can be suggested that the works covered by the activity book prepared for visual arts should be updated to bring sufficient and necessary contribution to the artistic development of gifted students.

- The learning environment for the teaching of visual arts should not be limited to the school building and class, and students' learning can be supported through various study visits, exhibitions and workshops.

- Educational activities offered at the science and arts centers should be updated and in consistent with the corrent conditions.

- The science and arts centers should be divided into science centers and arts centers. Such a division would make it possible for arts centers to be independent and much more significant. 


\section{Kaynakça / References}

Altıntaş, E. (2014). Üstün zekâlı öğrenciler için yeni bir farklllaştırma yaklaşımının geliştirilmesi ve matematik öğretiminde uygulanması. Yayınlanmamış doktora tezi, Marmara Üniversitesi, Eğitim Bilimleri Enstitüsü, İstanbul.

Aral, N. (1999). Sanat eğitimi yaratıcılık etkileşimi, Hacettepe Üniversitesi Ĕ̆itim Fakültesi Dergisi, 15, 11-17.

Baltacıŏlu, İ. H. (1971). Türk plastik sanatları, Ankara: Milli Eğitim Basımevi. Bildiren, A. (2011). Üstün yetenekli çocuklar: aileler ve öğretmenler için bir kulavuz. İstanbul: Doğan Kitap.

Bildiren, A. (2013). Üstün yetenekli çocukların öğrenme stillerinin belirlenmesi. Üstün Yetenekliler Ĕ̆itimi Araştırmaları Dergisi, 1(1), 10-21.

Buyurgan, U. (2012). Sanat eğitimi ve öğretimi. Ankara: PegemA Yayıncılık.

Büyüköztürk, Ş., Çakmak, E., Akgün, Ö., Karadeniz, Ş. ve Demirel, F. (2014). Bilimsel araştırma yöntemleri. (17. Baskı). Ankara: Pegem Yayıncılık.

Christensen, L. B., Johnson, R. B., ve Turner, L. A. (2015). Araştırma yöntemleri desen ve analiz. Ankara: Anı Yayıncılık.

Coleman, M. (2012). Interviews. In (Coleman, M., Briggs, A. R. J. ve Morrison, M. eds.) Research methods in educational leadership and management, ( $\mathrm{p}$. 250-266). London: Sage.

Cutts, N. E. ve Moseley, N. (2004). Üstün zekâlı ve yetenekli çocuklarm eğitimi (Çev. İsmail Ersevim), İstanbul: Özgür Yayınları.

Creswell, J. W. (2007). Qualitative inquiry and research design: Choosing among five approaches (2nd ed.). Thousand Oaks., CA: Sage.

Gliner, J. A., Morgan, G. A., ve Leech, N. L. (2015). Uygulamada araştırma yöntemleri: desen ve analizi bütünleştiren yaklaşım. Ankara: Nobel Akademik Yayıncilik.

Danış, S. (2017). Bir eğitim aracı olarak sanatın üstün yetenekli bireylerin eğitim ve rehabilitasyonunda kullanılması. International Journal of Social Science, 59, 163-172.

Hurwitz, A. ve Day, M. (1995). Children and their art (Methods for the elementary school), Florida: Harcourt Brace College Publishers.

Kansu Çelik, F. (2015). "Üstün zekalı bireylerin görsel sanatlar eğitimine ilişkin tutumlarının incelenmesi", (Yayınlanmamış yüksek lisans tezi), Marmara Üniversitesi, İstanbul. 
Karasar, N. (2015). Bilimsel araştırma yöntemleri, Ankara: Nobel Akademik Yayıncilik.

Karip, F. (2016). Görsel sanatlar öğretmenlerinin görsel sanatlarda üstün yetenekli öğrencilerin eğitimine yönelik farkındalıkları ve uygulamalar: Ağrı ili örneği. Üstün Zekâlılar Ĕ̆itimi ve Yaratıcılık Dergisi, 3(1), 17-31.

Levent, F. (2011a). Üstün yeteneklilerin eğitimine yönelik görüş ve politikaların incelenmesi. Yayınlanmamış doktora tezi, Marmara Üniversitesi, Eğitim Bilimleri Enstitüsü, İstanbul.

Levent, F. (2011b). Üstün yetenekli çocukların hakları. İstanbul: Çocuk Vakfı Yayınları.

Levent, F. (2014). Üstün yetenekli çocukları anlamak (3. Baskı), Ankara: Nobel Akademik Yayıncılık.

Levent, F. ve Kansu-Çelik, F. (2017). Sanat alanında üstün yetenekli çocukların eğitiminin devlet tarafından desteklenmesine ilişkin sanatçıların görüşleri. Türk Üstün Zekâ ve Eğitim Dergisi, 7(2), 65-86.

MEB. (2015). Bilim ve Sanat Merkezleri Yönergesi. 14.01.2019 tarihinde https://orgm.meb.gov.tr/meb_iys_dosyalar/2016_10/07031350_bilsem_yonergesi.pdf adresinden erişilmiştir.

MEB. (2012). Özel Ĕ̆itim Hizmetleri Yönetmeliği. 14.01.2019 tarihinde http://orgm.meb.gov.tr/meb_iys_dosyalar adresinden erişilmiştir.

Mercin, L. ve Alakuş, A. O. (2007). Birey ve toplum için sanat eğitiminin gerekliliği, D.Ü. Ziya Gökalp Eğitim Fakültesi Dergisi, 9, 14-20.

Merriam, S. B. (2013). Nitel araştırma desen ve uygulama için bir rehber. Ankara: Nobel Akademik Yayıncılik.

Moseley, N. ve Cutts, N. E. (2004). Üstün zekâlı ve yetenekli çocukların ĕğitimi, İstanbul: Özgür Yayınları.

Özkan, D. (2009). Yönetici, öğretmen, veli ve öğrenci görüşlerine göre bilim ve sanat merkezlerinin örgütsel etkililiği. Yayınlanmamış yüksek lisans tezi, Ankara Üniversitesi, Ankara.

Özer Keskin, M., Keskin Samanc1, N., ve Aydın, S. (2013). Bilim ve sanat merkezleri: mevcut durumları, sorunları ve çözüm önerileri. Üstün Yetenekli Ĕ̆itimi Araştırmaları Dergisi, 1(2), 78-96.

Renzulli, J. S., ve Reis, S. M. (1985). The schoolwide enrichment model: A comprehensive plan for educational excellence. Mansfield Center, CT: Creative Learning Press. 
Robinson, A., Shore, B. M., ve Enersen, D. L. (2007). Best practices in gifted education: An evidence-based guide. Waco, TX: Prufrock Press.

Sak, U. (2010). Üstün zekâlılar: özellikleri tanılanmaları eğitimleri. Ankara: Vize Yayıncilik.

San, İ. (1979). Sanatsal yaratma ve çocukta yaratıcılık. İstanbul: Türkiye İş Bankası Kültür Yayınları.

Sezginsoy, B. (2007). Bilim ve sanat merkezi uygulamalarının değgerlendirilmesi. Yayınlanmamış yüksek lisans tezi, Balıkesir Üniversitesi, Balıkesir.

Silverman, D. (2006). Interpreting qualitative data. (3rd Ed.). London: Sage.

Şenol, C. (2011). Üstün yetenekliler eğitim programlarına ilişkin öğretmen görüşleri: BILLSEM örneğgi. Yayınlanmamış yüksek lisans tezi, Fırat Üniversitesi, Elazı̆̆.

TBMM. (2010). Üstün yetenekli çocukların keşfi, eğitimleriyle ilgili sorunların tespiti ve ülkemizin gelişimine katkı sağlayacak etkin istihdamlarının sağlanması amacıyla kurulan meclis araştırması komisyonu raporu.

(Rapor No: 427) 14.01.2019 tarihinde https://www.tbmm.gov.tr/arastirma_komisyonlari/ustun_yetenekli/docs/Kurulu\%C5\%9F\%20Karar\%C4\%B1\%20Tutanaklar\%C4\%B1\%206.03.2012.pdf_adresinden erişilmiştir.

Yavuzyılmaz, B. (2012). Bilim ve sanat merkezlerine devam eden 7-11 yaş üstün yetenekli çocuklara verilecek sanat eğitiminin niteliği. Yayınlanmamış yüksek lisans tezi, On Dokuz Mayıs Üniversitesi, Samsun.

Yetkin, S. K. (1962). Sanat meseleleri. İstanbul: De Yayınevi.

Yıldırım, A., ve Şimşek, H. (2016). Sosyal bilimlerde nitel araştırma yöntemleri. Ankara: Seçkin Yayıncılık.

Yıldız, H. (2010). Üstün yeteneklilerin eğitiminde bir model olan bilim ve sanat merkezleri (BÍLSEMLER) üzerine bir araştırma. Yayınlanmamış yüksek lisans tezi, Gazi Üniversitesi, Ankara.

Yılmaz, M. (2007). Görsel sanatlar eğitiminde işbirlikli öğrenme, Kastamonu Eğitim Dergisi, 15, 747-756.

Yolcu, E. (2009). Sanat eğitimi kuramları ve yöntemleri, Ankara: Nobel Akademik Yayıncilik.

Yücel, H. S. (2012). Üstün yetenekli çocukların, çok alanlı sanat eğitimi yöntemini kullanarak sanat tarihi alanında gerçekleştirdikleri müze gezisinin sanatsal uygulamalarına etkisi. Sosyal Bilimler Dergisi, 2(2), 63-101. 


\section{Kaynakça Bilgisi / Citation Information}

Levent, F. ve Kansu-Çelik, F. (2019). Bilim ve sanat merkezlerinde görev yapan görsel sanatlar öğretmenlerinin özel yetenekli öğrencilerin sanat eğitimine ilişkin görüşleri. OPUS-Uluslararası Toplum Araştırmaları Dergisi, 13(19), 750-785. DOI: 10.26466/opus.581375 